Jacobson, Miriam.

\title{
Barbarous Antiquity: Reorienting the Past in the Poetry of Early Modern England.
}

Philadelphia: University of Pennsylvania Press, 2014. Pp. $286+13$ ill. ISBN 978-0-8122-4632-2 (hardcover) \$59.95.

Miriam Jacobson's argument in Barbarous Antiquity is that English trade with the Ottoman Empire in the late sixteenth and seventeenth centuries recast the relationship between English and classical literatures. Focusing on narrative poetry by Shakespeare, Marlowe, and Chapman and poetics by Jonson and Puttenham, Jacobson shows how imported words, metaphors, and concepts "inaugurate[d] a new poetic economy, reconfiguring cultural attitudes toward ancient and modern, East and West, and redefining what it meant to write and publish poetry in English during the Renaissance" (4). Jacobson's account is richly evocative of the sensory and intellectual experiences she documents: the ingenuity and intricacy of sugar confections, the limpid sheen of the orient pearl, the power and heat of the Arabian horse, the exquisite tracery of the fritillary flower, and the people, words, and poetry that brought them from one place to another and back again. Barbarous Antiquity reorients us, in both senses of the word: it causes us to reappraise our location and surroundings, as early modernists, and it turns us (again) towards the East.

The first chapter, "Strange Language: Imported Words in Jonson's Ars Poetica [and Poetaster]," focuses on the influx of "inkhorn terms," or new words, especially those that derive from the early modern Levantine trade network. On the one hand, Jonson overtly resists and rejects inkhorn terms that contaminate the plain and classical style he espouses, but on the other, he finds the manipulation, hybridization, and supplementation of words to be irresistible. In Poetaster, for instance, the "antique" is also the antic, and canonical classical literary values are over-written by the prodigious, scatological, and viscous words that "ooze, froth, and seep out of the body's orifices with [...] revolting zest" (46).

The second chapter concerns Puttenham's Arte of English Poesie and the introduction of sugar into the European kitchen. When sugar became commonly available, it replaced honey as the metaphor for the "sweetness" of poetry. But sugar is very different from honey, and has extraordinary properties: "sugar was more than a sweetener; it was a spice, a medicine, an artistic medium, and a powerful tool of material transformation and manipulation" (69). As 
part of the metaphoric apparatus through which poetry was understood, then, sugar changed how poetry was thought to work: "If, like sugar, verse could be molded, stretched, and spun fine, then poetry had remarkable abilities to animate and move readers and listeners in the same way" (65). The use of oriental "sugar" in Puttenham's work is one way in which he engineers the renovation of the formal models and origins of English poetry that the Arte effects, whereby occidental antiquity, in the form of Greek and Latin models, is supplanted by oriental modernity, itself mediated, malleable, and in flux.

The second section of the book focuses on Shakespeare's narrative poems. Chapter 3, "Publishing Pain: Zero in The Rape of Lucrece," is about the integration of the Arabic notion of the "cipher," or zero, and its calligraphic and printed representations, into the Ovidian tale. The preoccupation in the poem with images of writing and of textuality draws our attention to "the graphic shape of Lucrece's violation and pain (O and o)" which "elevate[s] her silent suffering to material textual status that can be printed, reproduced, and circulated" (90). The new, "oriental" figure of zero, especially when written or printed, makes visible Lucrece's rape and loss, thereby re-writing Ovid's and Plutarch's versions of the story.

Chapter 4, "Breeding Fame: Horses and Bulbs in Venus and Adonis," centres on additions Shakespeare makes to Ovid's story, particularly the elevenstanza description of horse mating, and the metamorphosis of Adonis into a flower which is "purple [...] chequered with white," in distinction from Ovid's blood-red anemone. Both Arabian horses and the fritillary flower bulb were Turkish imports, and both represented renewed fertility and the potential for generation "within a poem about incompatibility, failure, and loss in love" (115). The revision of the poem is also a revision of the temporal relationship between the modern and the ancient, as the antique is renewed at its roots by the modern, and of the spatial relationship between the West and the East, as the classical East comes to inhabit, and thereby estrange, the topoi of the modern West.

The last chapter is about Hero and Leander in the 1598 edition, begun by Christopher Marlowe and completed by George Chapman. Jacobson casts the contrast between Marlowe and Chapman in terms of their use of the literal, symbolic, and metaphoric references to eastern commodities. "Marlowe's imagery of orient pearls represents freedom from Western mores, and the dynamic and protean space of the Hellespont becomes a body of water that queers its subjects as much as it divides East from West" (24); for Chapman, 
the commodities in play are dyes and inks, tools of dissimulation and deceit, and the Hellespont, as a result, "is a heavily policed and regulated space" (24). Both poets used the nexus of Ottoman-inflected words, things, and places to reframe the classical literary heritage and the relationship of English writingitself marked by its "own barbarous past" (187) — to early modernity.

The orientation towards the Ottoman East that provides the backbone of Jacobson's argument waned with the development of the western empire in the Americas. Nonetheless, as she writes in the conclusion, the unmooring of the national literature from particular classical times and spaces, and the complex relationships between things, words, and poetry that Levantine trade subtended, had persistent effects in later English literature.

KATHERINE ACHESON

University of Waterloo

\section{Kerr, Rosalind.}

\section{The Rise of the Diva on the Sixteenth-Century Commedia dell'Arte Stage.}

Toronto: University of Toronto Press, 2015. Pp. xiii, $216+25$ ill. ISBN 978-14426-4911-8 (hardcover) \$65.

Kerr traces the presence of women on the Italian Commedia dell'Arte stage from the 1560s through the early seventeenth century, describing how their roles evolved with the infusion of commedia erudita's tropes into their popular performance genres and how the infusion catalyzed a concomitant evolution in audience perception of the woman performer from titillating acrobat to aweinspiring diva. Drawing on performance and feminist theory, Kerr sees the process beginning when the magic of theatre filled the void created by "the loss of belief in the sacred" (4), a characterization that could be disputed by some scholars of religious life. According to Kerr, the new presence of women, first in piazza performances and much earlier than in other European countries, resulted in the subsequent "fetishizing" of female bodies through their display in the service of material commerce (5). It also provoked the resentment of ecclesiastics by adding the very erotic element excluded from Christian ritual.

The transition to diva was aided by the cortegiana honesta, whose artistic accomplishments and restraint of her erotic activities made her a more 